\title{
A Study on Costs, Risks and Competitiveness of Palm Oil Fruit Dealers' Business in Malaysia
}

\author{
Ahmad Raflis Che Omar ${ }^{1, *}$, Suraiya Ishak ${ }^{2}$, Abd Hair Awang ${ }^{2}$ \& Mohd Yusof Hussain ${ }^{2}$ \\ ${ }^{1}$ School of Management, Faculty of Economics and Management, Universiti Kebangsaan Malaysia, Bangi, Selangor, \\ Malaysia \\ ${ }^{2}$ Social, Environment and Developmental Sustainability Research Centre (SEEDS), Faculty of Social Sciences and \\ Humanities, Universiti Kebangsaan Malaysia, Bangi, Selangor, Malaysia. \\ *Correspondence: School of Management, Faculty of Economics and Management, Universiti Kebangsaan Malaysia, \\ Bangi, Selangor, Malaysia. E-mail: raflis@ukm.edu.my
}

Received: March 30, $2018 \quad$ Accepted: April 29, $2018 \quad$ Online Published: May 7, 2018

doi:10.5430/sass.v5n2p18 URL: https://doi.org/10.5430/sass.v5n2p18

\begin{abstract}
This exploratory study aims to describe the nature of palm oil intermediary business focusing on the costs structure, risks and competitive challenges. This study employs qualitative research design. Five fruit dealers (FD) are involve in the interview. The findings show that palm oil fruit dealer business requires enormous amount of cash and equipment investments during the start-up and growth stages. In addition, FDs must comply with specific requirements to apply for the operating license. The risks are divided into non-controllable and controllable risks. The non-controllable risk refers to the external source of risks such as fresh fruit bunch (FFB) shrinkage due to weather factor, volatility of market price and inconsistent mills purchase decisions. Meanwhile, the controllable risk consist of the probability of unripe FFB purchased from the smallholders. Furthermore, the finding indicates that the business competitive structure is relatively intense due to strong bargaining power of buyers and sellers, high service substitutability from nearby FDs, high rivalry among existing firms, and the need of special equipment. However, the threat of new entrants is low due to the high entrance and exit barriers of the business. Finding of this study suggested that agriculture intermediaries have important roles within the palm oil smallholders' value chain. Therefore, this study disseminates preliminary insights on FDs' business in terms of costs, risks and challenges.
\end{abstract}

Keywords: agriculture, intermediaries, palm oil, fruit dealers

\section{Introduction}

Profit and wealth accumulation have always been the motive for most business establishment (Dolenc et al., 2012; Kuratko et al., 2011; Watson 2002 and Friedman 2004). The entrepreneurs invest enormous resources and effort to initiate and grow their businesses. They accept and manage all kind of business risks, costs and challenges in order to deliver values to the respective targets (Kanchana et al., 2013; Caggese, 2012; Vesković, 2014; Watson, 2002; Zichella, 2015; and Barber et al, 1989). Thus, it is rather simplistic to judge a business merely on the outcome without prior understanding on the risks and challenges being exposed. The knowledge gap of the particular business nature may lead to misunderstanding of certain business behaviors and strategies. As a result, corrective actions to fix any misbehavior or/and problems becomes ineffective due to the incomplete understanding of the real problem(s) underlying particular behaviors or decisions. The agriculture intermediaries business is subjected to similar context too. Agriculture intermediaries resemble one of the locally based agribusiness in the market. As far as developing countries are concern, the agribusiness enterprises refer to the typically small to medium scale operations in rural areas that either process raw agricultural materials or provide marketing, transport and other services (Stanton, 2000). According to Stanton (2000), the role of local based agribusiness is necessary to the small agriculture producers. The agribusiness owners invest capitals and accept certain costs, risks and challenges to provide services for the clients (Mahfoor et al., 2001). Thus, this article describes the nature of one of the agribusiness players in the Malaysian palm oil sector, which are the fruit dealers (FD). In order to get an overview of the Malaysian palm oil sector, next 
sub-section will elaborate on the history and nature of the palm oil supply chain activities in Malaysia. The discussion provides the contextual explanation to highlight the niche and gap in the study of palm oil fruit dealers business.

\section{The Malaysian Palm Oil Agriculture Sector}

The origin of palm oil (or its scientific name Elaeis Gunineensis Jacq.) can be linked to the West Africa. The plantation of palm oil in South East Asia started in the Botanic Garden of Bogor Sumatra in 1848 (Teoh, 2002). The commercial development of palm oil plantation in Malaysian began as the Frenchman, Henri Fauconnier, purchased some palm oil seeds during his visit to Sumatra. He planted the seeds at his Rantau Panjang, Selangor estate in 1911. Fauconnier returned to Sumatra to obtain more seeds and eventually established the first commercial palm oil planting at the Tennamaram estate in Ijok Selangor to replace the unsuccessful planting of coffee (Tate 1996 in Teoh 2002).

Referring to Teoh (2002), there are authors who segregated the development of the palm oil industry in Malaysia into three (3) phases; during late 1800s; early of 1900 to 1916 and 1917 to 1960 . The first two phases were the experimental phase and the third phase commencing from 1917 onwards refer to the plantation development phase. In addition, following the 1960, the development has been referred as the expansion phase due to the changes in the Malaysian government policy which attempt to reduce national economic dependencies on the natural rubber. Eventually, palm oil industry has turned as the major export incomes for Malaysia and contributes significantly to the revenue of the Malaysian economy for many years (Affendy et al., 2013; Elaine \& Adam 2011; and Mohammad et al., 1992). Based on the study by Affendy et al. (2013), Malaysia is more competitive in most of its downstream palm oil related industries.

Although Fruit Dealers (FDs) play important role within the supply chain of palm oil smallholders in developing country, not so much known about the business. Referring to Stanton (2000), small agriculture producers faced constraints such as limited access to capital, technical assistance, and competitive buyers. Correspondingly, fruit dealers are among the local business activities that able to provide necessary aids for the smallholders especially in the developing and emerging economies context. The local agribusiness able to fill up the diminishing role of government to uphold the income and livelihood in rural areas (Stanton, 2000).

Next section explains activities and major players of palm oil sector in Malaysia. The explanation provides overview on the FDs involvement within the context of small holders value chain.

\subsection{Major Players of Palm Oil Supply Chain}

The supply chain of the palm oil involves many activities and participants. The process began with the produce of fresh fruit bunch (FFB) by planters or farmers. Upon completion of harvesting activity, the FFB will undergo additional processes prior to the production of varieties of palm oil based products. Based on Teoh (2002), seven (7) major players within the palm oil industry in Malaysia are identified as follows:

(a) Upstream producers who involved in the cultivation of oil palm, production of FFB and processing them into crude palm oil and palm kernel;

(b) Downstream producers comprised of palm oil refiners, palm kernel crushers, manufacturer of palm-based edible products and specialty oils and fats;

(c) Exporters and importers of palm oil;

(d) Customers- institutional buyers and retail customers and investors;

(e) Industry organizations representing the interest of the upstream and downstream producers;

(f) Government agencies associated with the oil palm industry particularly in respect of research and development and regulatory functions;

(g) Other players who have interests and stake in the oil palm industry (NGOs and unions etc).

The upstream players comprise of the private plantation companies, government owned entities such as Felda, government schemes and individual smallholders. Those entities participate as the planters or producers of palm oil commodity in the country. The independent smallholders refer to the unorganized farmers with farm size of less than 4 Ha (Mohamed Amine, 2016). Despite the uneconomic plantation scale, the smallholders contributed significantly to the palm oil sector in Malaysia. The contribution is obviously evidence through the statistic of distribution of palm oil planted area by state and sector in 2016. Based on Table 1, independent smallholders contribute about 19.07 
percent of the palm oil planted in Peninsular Malaysia, 14.29 percent in Sabah and 13.36 percent in Sarawak respectively. In addition, smallholders' plantation formed about 16.28 percent of the Malaysian palm oil planted area, which is the next largest following the private estates (61.15 percent).

Table 1. Malaysia: Distribution of Oil Palm Planted Area by State and Sector in 2016 (Hectares)

\begin{tabular}{|c|c|c|c|c|c|c|c|}
\hline \multirow[t]{2}{*}{ State } & \multicolumn{6}{|c|}{ Sectors } & \multirow[t]{2}{*}{ Total } \\
\hline & Smallholders & Felda & Felcra & Risda & $\begin{array}{l}\text { Government } \\
\text { Related } \\
\text { Agencies }\end{array}$ & $\begin{array}{l}\text { Private } \\
\text { Estates }\end{array}$ & \\
\hline Johor & 213,396 & 133,528 & 22,258 & 3,215 & 39,684 & 333,549 & 745,630 \\
\hline Kedah & 25,347 & 717 & 837 & 769 & 2,520 & 57,596 & 87,786 \\
\hline Kelantan & 5,465 & 36,690 & 1,841 & 501 & 19,916 & 91,045 & 155,458 \\
\hline Melaka & 11,905 & 2,460 & 2,463 & 1,578 & 304 & 37,439 & 56,149 \\
\hline Negeri Sembilan & 25,093 & 46,138 & 7,279 & 8,193 & 520 & 91,735 & 178,958 \\
\hline Pahang & 48,073 & 297,541 & 32,760 & 22,931 & 73,615 & 257,132 & 732,052 \\
\hline Perak & 115,369 & 22,690 & 27,055 & 14,989 & 18,900 & 198,905 & 397,908 \\
\hline Perlis & 82 & 457 & 113 & - & - & - & 652 \\
\hline Pulau Pinang & 9,078 & - & 472 & - & - & 4,585 & 14,135 \\
\hline Selangor & 45,195 & 6,655 & 1,871 & 281 & 3,535 & 81,294 & 138,831 \\
\hline Terengganu & 12,001 & 39,051 & 17,632 & 19,092 & 10,635 & 73,532 & 171,943 \\
\hline Peninsular & 511,004 & 585,927 & 114,581 & 71,549 & 169,629 & $1,226,812$ & $2,679,502$ \\
\hline$\%$ & 19.07 & 21.87 & 4.28 & 2.67 & 6.33 & 45.79 & 100.0 \\
\hline Sabah & 221,678 & 105,034 & 15,043 & - & 89,473 & $1,120,486$ & $1,551,714$ \\
\hline$\%$ & 14.29 & 6.77 & 0.97 & - & 5.77 & 72.21 & 100.0 \\
\hline Sarawak & 201,266 & 15,627 & 43,408 & - & 85,212 & $1,161,256$ & $1,506,769$ \\
\hline$\%$ & 13.36 & 1.04 & 2.88 & - & 5.66 & 77.07 & 100.0 \\
\hline Malaysia & 933,948 & 706,588 & 173,032 & 173,032 & 344,314 & $3,508,554$ & $5,737,985$ \\
\hline$\%$ & 16.28 & 12.31 & 3.02 & 1.25 & 6.00 & 61.15 & 100.0 \\
\hline
\end{tabular}

Source: Malaysian Palm Oil Board

(www.kppk.gov.my/,pic/index.php/statistik-komoditi/2016-06-30-04-32-55/710-statistik-komoditi-sawit)

Nevertheless, the identification of the palm oil industry upstream players has not highlighted the existence and roles of FD. As a result, the identification of palm oil industry players is incomplete due to the absence of FD entities. The situation potentially explained the dearth of studies on the palm oil supply chain with connection to FDs business and activities.

A study by Mohamed Amine (2016) reiterates the relevance of fruit dealers in the upstream supply chain of the palm oil. According to Mohamed Amine (2016), the collection centers and dealers are the intermediaries between farmers and mills especially among the independent smallholders. Based on Ahmad Raflis et al. (2016) and Suraiya et al. (2016), the palm oil FDs in Malaysia performed the bulk purchaser task for smallholders' produces. Suraiya et al. (2016) describes two modes of FDs and independent smallholders' relationship as shown in Figure 1. The first mode involved situations in which the smallholders sell their FFB to any FDs in the area. The FDs act as the agglomeration center that gathered FFB from the local smallholders. The fresh fruit are purchased at market price and later on the FDs will sell and transport the FFB to the processing mills. 


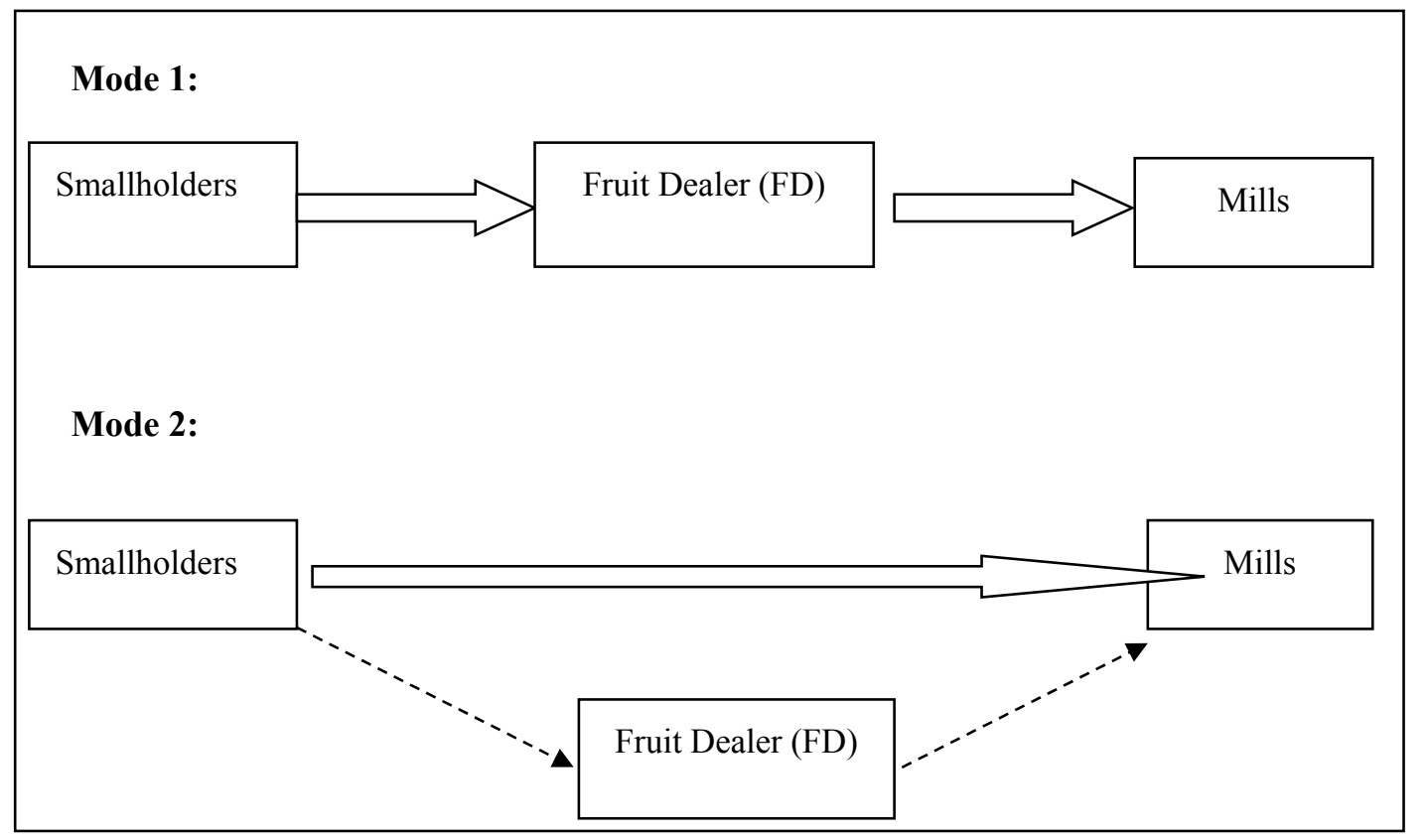

Figure 1. Structure of FFB Trading Within Smallholders Supply Chain

Source: Suraiya et al., (2016:50)

By contrast, the second mode involved situations in which the smallholders directly transport their FFB to the nearest mills. However, the sale transactions are record via specific FD's account maintained by the mills. The practice is such a way because the mills do not maintain sales record on the basis of individual farmers. Thus, the dotted line represents the indirect transaction between smallholders and FDs which mediated by FDs' account. Although the smallholders able to transport their FFB to the mills, the transaction record must still be recorded through the FDs' account. Thus, it reflects the importance of FDs'role in the smallholders' supply chain. Nevertheless, little are known about the FD's intermediary business. Therefore, the gap need is to be filled by an exploratory and descriptive study based on the FDs' experience.

The originality of this study lies in its effort to provide an overview of the nature of palm oil fruit dealers' business, which relatively understudied. This is parallel with Affendy et al. (2013) whom found a large residual gap in the existing literature of the palm oil studies. According to Affendy et al. (2013), the large gap was due to two (2) reasons. Firstly, the nature of palm oil industry is complex and many interrelated players with different activities, output, issues and contribution are involved. Secondly, the insufficient statistical information impedes the empirical studies on the economic and business potential of its subcomponents. Nevertheless, the environmental impact of palm oil plantation studies are relatively well documented (Affendy et al., 2013). For instance, studies by Richter (2009) and Awang Ali Bema et al. (2011) are among the current literatures, which discuss on the environment and social impacts of the palm oil production in Malaysia. Other studies such as Elaine \& Adam (2011) had looked on the issue of its downstream players. Elaine \& Adam (2011) examines the major cost of the palm oil mills that influenced the production cost of the crude palm oil (CPO). Their study employed qualitative research approach that involved two (2) mills. Nevertheless, research on palm oil fruit dealers of any topic are relatively scarce to date.

\subsection{Business Competitivess}

Porter Five (5) forces model is frequently used to evaluate the competitiveness of a market and/or industry (Boland 2010). Porter's Five Forces competitive position analysis was veloped by Micheal Porter in 1979. The five (5) forces which influence the competitive structure of the industry consist of (1) the bargaining power of suppliers, (2) bargaining power of buyers, (3) threat of new entrants, (4) threat of substitute products/services and (5) the rivalry among competitors. According to Porter's framework, the five factors will determine the competitive intensity and attractiveness of the market (Porter 2008). Additionally, the entrance and exit barriers are the important factors that determine the intensity of new entrants' threat in Porter's model. A study by Chladkova (2008) provides further insights regarding the entrance barriers for the agricultural production businesses. Based on Chladkova (2008) the 
entry barriers for agricultural business comprised of economies of scale, differentiations, capital intensity, access to distribution channels, government policy and anticipated retaliatory from existing firms. Boland (2010) further elaborated on the use of Herfindahl-Hirschman Index (HHI) to measure firm concentration of a particular industry. HHI take into account the relative size and distribution of the firms in the market. An intriguing study by Olson and Boehlje (2010), provides a modified version of the Five Forces framework model which meant to explain the competitive scenario for agribusiness value chain. The components of the modified forces for agribusiness value chain consist the following:

(a) Bargaining power of suppliers;

(b) Bargaining power of buyers;

(c) Threat of new entrants;

(d) Threat of substitute products and services;

(e) Rivalry among existing firms;

(f) Technology; and

(g) Other drivers of change such as government policy and regulation, taxes, and demographic changes.

Hence, the Porter Five Forces model will be used to guide the understanding of the palm oil fruit dealer competitive business structure.

\section{Methodology}

A qualitative research aims to address questions concerned with developing an understanding of the meaning and experience dimensions of human lives and social world (Fossey et al., 2002). The qualitative approach moves inductively because it elicit participants' views of their lives/activities as portrayed in their own story and to gain access to their feelings, experience and social world. The qualitative research findings are presented as textual descriptions that illuminate the subjective meanings of the phenomena or social world, being studied so as to represent the real world of those studied and in which their lived experience are embedded (Fossye et al., 2002). The qualitative field research is different from the quantitative because the data and observations are not easily reduced to numbers or figures (Babbie, 2004). Although the qualitative data may have disadvantages of purely verbal descriptions, but it is useful to explore new area which is poorly understood (Fossye et al., 2002).

This study aims to explore and describe the nature of FD business in terms of exposed costs, risks and challenges. Thus, the purpose fit the qualitative research design that attempt to discover new knowledge based on the subjective perspective, feelings and experience of the fruit dealers. Specifically, this study involves interview with five (5) fruit dealers (FD) in Selangor. Semi-structured questions were developed to guide the interview session. The interview sessions took approximately 2 hours per FD and was conducted at the FD's business premise. The selection of FDs are made through the non-probability sampling namely the purposive sampling. The profile of the informants are shown in Table 2.

Table 2. Informants' Profile

\begin{tabular}{ccc}
\hline Respondent & $\begin{array}{c}\text { Year Commencing as } \\
\text { FD }\end{array}$ & Education Level \\
\hline A & 1995 & Malaysian Education Certificate (SPM) \\
B & 2003 & Lower Certificate of Education (SRP) \\
C & 2007 & Bachelor degree \\
D & 2000 & IKM certificate \\
E & 2015 & SPM \\
\hline
\end{tabular}

\section{Analysis}

This section represents the descriptions of FDs business according to the interview findings. The informant transcripts are present as the evidence to support the identified patterns and/or themes. This is parallel with Fossye, et 
al. (2002) who elucidated qualitative data are analyzed either through the meaning-focused or discover-focused techniques. Our explanation is divided into three (3) sub topics comprise of (1) services offered by FDs business; (2) nature of FDs costs and risks exposures; and (3) the competitive challenges of the FDs operations.

\subsection{Fruit Dealers Services}

All informants provide the purchase of FFB as the main service to local independent smallholders of the respective areas. The FDs purchased the FFB from local smallholders and pay them in cash according to market price after deduction of some agreed charges such as transportation charge and repayment of credits. Respondent $\mathrm{E}$ offers two modes of payments according to the small holders' demand. The first mode is the cash upon receiving the FFB and the second is the cumulative monthly based cash payment. For the monthly payment mode, the smallholders sell the FFB to Respondent $\mathrm{E}$ and the accumulated proceeds are disbursed at the end of the month. According to Respondent $\mathrm{E}$, the smallholders are free to choose the payment mode they preferred.

Besides FFB purchase, local FDs also provide other services as depicted in Table 3. Based on Table 3, FD services are split into two themes: the commercial and the social based services. The purchase of FFB falls under the commercial category. Thus, all FDs will at least provide the commercial based service, which is purchase and sell of FFB. The trading activities encompass of FFB purchase from the local smallholders and selling it to the palm oil processing mills. Additionally, the FDs provide transportion services throughout the FFB purchase and selling process.

Apart from the purchase of FFB and the sale of agricultural inputs, farm management is becoming an important commercial service provided by the FDs. Farm management becomes important because most of the smallholders in the area are unable to manage the farm on their own due to age factor or unable to hire workers. There is also situation the owner has migrated to other places. As a result, they hire the FDs to manage the farm and collect the sales proceeds from the FDs such described as follows:

\section{Respondent D:}

"She is a doctor...She did not live here (referring to a woman in her 30's who arrives at the premise during the interview session). The farm actually belongs to her late father and her father gave the farm to her. So we help to manage the farm. She only comes back once a while to collect the money. I think she's on leave today There are about 10 like her (meaning that other smallholders who use the farm management service).

\section{Respondent A:|}

"Most of them (smallholders in his area) did not manage their farm themselves. They hire another party to do it. I think $75 \%$ hire other to manage, only 25\% manage the farm on their own. Because... in here most people have paddy field (local people called bendang) and palm oil farm. The bendang need more close attention, so most of these people prefer to handle and manage their bendang themselves. (Whereas) the palm oil...you don't need to take care of it like the paddy. So that's why they hire other people to do the farming on their behalf"

Based on Table 3, the FDs also provide transportation service to move the smallholders' FFB from the farm to FDs premise. The transportation service is important because the smallholders usually do not possess their own transport. It is uneconomic for the smallholders to rent/charter a truck for transporting a relatively small quantity of FFB. Moreover, the distance between the oil palm mills and the small holder's farms are considerably far. Most of the informants reported that they send the FFB to the processing mills in Teluk Intan, Perak (Respondent A), Air Kuning and Tanjung Tualang, Perak (Respondent B) and Bidor Perak (respondent D). Three (3) informants (A, B and C) have charged the smallholders about RM 20 per tonne as the transportation fee. Respondent D charged a slightly lower rate which is RM 10 per tonne. Contrary, Respondent E did not provide transportation services to collect FFB from the smallholders' plantation site. Respondent E merely purchased the FFB from the local smallholders and the smallholders need to send the FFB to his premise on their own transport. Respondent E only transporting the FFB from his premise to the particular processing mills as shown by the following explanation. 
Table 3. Fruit Dealers' Services

\begin{tabular}{lll}
\hline No. & Themes: Commercial Services & Interview transcripts \\
\hline 1 & Logistic \& Transportation services & Respondent A \\
& "we provide services but with charge such as transportation, collecting the fruits from \\
& their farm, we charge them RM 20 per tonne...the smallholders don't need to do \\
& anything, they just watch us doing the task [on behalf of them]..."
\end{tabular}

\section{Respondent D}

"Yes.. we collect from their [smallholders] place. We have our own truck. We charged them RM10 per tonne for this..."

$2 \quad$ Farm management services

3. Sell of agriculture inputs such as seeds, fertilizer and pesticides (cash and credit)

\section{Themes: Social aids}

4. Advancement/ Cash loan

\section{Respondent A:}

"Most of them (smallholders in his area) did not manage their farm themselves. They hire another party to do it. I think $75 \%$ hire others to manage, only $25 \%$ (of the smallhodlers) manage on their own..."

"I help them from the labour (workers) until to the crane"

\section{Respondent B:}

"The farmers don't have many children. [So] who wants to look after the farms? Besides, their children did not stay here. If we observe, no local people wants to do this difficult and dirty task. They come to visit their parents once in a while, they won't go to the farm to do all those jobs. All these are done by the foreign workers. Most of the farmers are getting older and unable to do on their own..."

\section{Respondent D:}

"plucking, fertilizing, pruning, provide seeds, some even as us to manage everything from A to Z, I think there are 10 of them who hire us to manage their farm on behalf of them [with specific charges]"

\section{Respondent A:}

"We provide credit for fertilizer and pesticides purchase. We deduct it from sale proceed when they sell fruits to us..."

\section{Respondent A:}

“...when their children want to go universities,..... we give them, [they] want to go for pilgrimage, not enough money, we also give them. Most of the time we give them cash"

\section{Respondent B:}

"I give loan to them. I treat it as debt. No interest charged. During their emergency they come and borrow from us...most of the time, when the school season begin."

\section{Respondent C:}

"Sometimes they want to use money. At night they call to borrow. I have so many cases. There are 2-3 persons who used to borrow repeatedly. When they had settled their previous loan, they will borrow again. That's how things work...".

\section{Respondent E:}

"Basically my main service is FFB purchase. I don't have other services. But the credit, yes, I provide cash loan for a few of them (refer to the smallholders). I think about $10 \%$ of (my) total client (smallholders) get credit from me" 


\section{Respondent E:}

"No...no...I don't provide transportation. (We) never collect the FFB (at their site), they have to arrange their own transport to bring the FFB here. Some (have) request (us) to arrange for the transportation. In that case I just help to arrange with the truck owner. The rest, they handle directly with the owner. But from this premise to the mills, yes..., I have my own truck to bring the FFB there"

Respondent E's action can be explained by two potential reasons; (1) the area is nearer to the town, thus the local smallholders have more access to transportation services from transportation providers; and/or (2) he is relatively new in the market (he started the business in 2015) and unable to identify additional opportunities in the palm oil dealer's market. On the other hand, four (4) FDs have also supply the farming materials such as fertilizer, seeds and others, either on cash or credit basis to the smallholders.

As a result, the commercial services are the main type of services offered to assist the smallholders' value chain. The services are charged and frequently used by the smallholders. The services are necessary because the mills do not conduct direct FFB purchase with individual palm oil smallholders.

\subsection{Business Costs \& Risks}

Table 4 presents information on the set-up cost for FDs business. Based on Table 4, a large amount of cash investment are required at the birth stage of the venture. According to the respondents' experience, the amount of cash required for business start-up ranged from RM 50,000 to RM 300,000. Two (2) FDs managed to obtain bank loans to purchase physical assets, while others used personal cash and pooled investment to start the business. All of the respondents used cash to purchase basic machineries/equipment and to finance the working capital at the early stage.

Table 4. Set-Up Cost for Fruit Dealers Operation

\begin{tabular}{rcccc}
\hline No. & Respondent & Cash Capital & Physical Assets & Source \\
\hline 1. & A & RM 50,000 & RM 25,000 & Pool investment \\
2. & B & RM 100,000 & RM 80,000 & Personal source \\
3. & C & RM 110,000 & RM 30,000 & Personal \& bank loan \\
4. & D & RM 30,000 & RM 80,000 & Personal \\
5. & E & RM 300,000 & No information & Personal source \\
\hline
\end{tabular}

Based on Table 4, the cumulative cost of the physical assets ranged from RM 25,000 to RM 80,000. The assets comprise of basic equipment for fruit dealers' operation comprise of the forklift, ramp, trucks, and graders as stated by particular respondents:

\section{Respondent A:}

"50\% (of the beginning cash capital) was used as my working capital. Another RM 25,000 to purchase the assets"

\section{Respondent B:}

"Just for the scale, I already spent there about RM 40,000. I think the total of all equipment is about RM 80,000 "

\section{Respondent D:}

"At least RM 30,000 to start (this business). The grader already cost us about RM 10,000. The ramp, we purchased last time about... RM 15,000 to RM 20,000...."

Additionally, Respondent A shares his experience and observation regarding the rising pattern of the fruit dealer business start up cost due to the changes in current business environment:

\section{Respondent A:}

"I have been in this business for 20 years. I was lucky (that) I had started at that time. (refering to 1995) I don't need road tax for my lorry, loading price is cheap, workers' wage is also cheap. Last time the cost is relatively low. No problem at all. Even I started this business with only RM 80 per tonn. At that time, the 
villagers come once a week with their crops. But now it's different. Nowadays, the fruits not even here, yet but (they) already ask you for money...."

The changing forces affect the overall cost of the palm oil dealer business startup due to the dynamic in the agriculture labors supply, wages and inflation rate. Meanwhile, the normal operating expenditure for FD business consist of a few major items, namely the transportation cost, wages and salary, overhead and maintenance. The estimation of the operating cost for palm oil fruit dealer business based on the respondents' experience is between RM 12,000 to RM 15,000 per month.

Table 5 indicates the current market value of the cash and physical assets of respective FDs. It reflects the current value of FDs investment in the particular business. The comparison between Table 4 and Table 5 shows the investment of cash and physical assets of each FDs have increased from time to time. Most of the respondents obtained bank loans to acquire additional equipment or improve the existing business capacity. For example, Respondent $\mathrm{A}$ and $\mathrm{D}$ informed that they did most of the task/activities manually during the beginning years. Later, they obtained a bank loan to purchase a forklift and new trucks to handle the business activities more efficiently. The FDs also increase their existing operating capacity through renovations of the premise.

Table 5. Current Value of Investment

\begin{tabular}{rcccc}
\hline No. & Respondent & Cash Capital & Physical Assets & Source \\
\hline 1. & A & RM 500,000 & RM 1,000,000 & Personal and Bank loan \\
2. & B & RM 200,000 & RM 300,000++ & Personal and Bank loan \\
3. & C & RM 130,000 & RM 170,000 & Personal and Bank loan \\
4. & D & RM 100,000 & RM 170,000-180,000 & Personal and Bank loan \\
5. & E & RM 400,000 & No information & No information \\
\hline
\end{tabular}

Based on the information in Table 4 and 5, the entrance and exit barriers of the business are considered as relatively high. As shown in Table 4, strong financial capacity is necessary in order to start the fruit dealer business. This situation reflects a high barrier for new market entrants to join the industry due to the expensive cost of business start up. Additionally the FDs must comply with the requirements set by the authority such as minimum ownership of palm oil plantation, distance among FDs premise, and minimum working capital. Meanwhile, Table 5 reflects the amount of cumulative investments that will turned into sunk cost if the FD decide to leave the fruit dealer business. The FDs found to have increased their investment through premise renovations and purchased of new equipments. Thus, a large amount of investment hinders their ability to exit from the market and the exit barrier is considered as relatively high.

Based on the interview, few risks found inherited within the fruit dealers' business. The risks have been grouped into a few themes as summarized in Table 6 .

The risk can be divided into controllable and non-controllable risks according to the FD's ability to exercise control over the risks. The uncertainty of accepting low quality of FFB from smallholders (item no. 3 in Table 6) is consider as a manageable risk by FDs. Based on the interview, we found that all FDs take strict action to prevent this risk. The FDs manage this risk through a thorough inspection upon receiving the fruit at their ramp. The FDs conduct the inspection themselves or entrusted the task to a qualified expert grader.

In terms of the non-controllable risk, all FDs merely accept the threat of the risks. They did not take any proactive actions to mitigate the risks. The unavailable of FFB market refer to the occasion in which the processing mills reject or did not want to purchase the FFB brought by the particular FDs. The situation usually occurs when the FFB is oversupply in the market, the processing capacity of mills has reached its maximum level, the mill preference towards certain FDs and/or the mills simply reject to purchase fruit from any particular FDs. The non-compliance of fruit standard refers to the risk that the FDs unaware or wrongly accept a low quality of FFB from the smallholders. Despite the thorough inspection, the bulk quantity of FFB sometimes distorts the manual fruit screening process. The commodity price fluctuation gives impact because FDs purchased the FFB from smallholders at a certain point of time and sell the FFB to the processing mills at other point of time in the future. Thus, differences in purchase and sell timing may lead to loss due to changes in the commodity price. Finally, weather is one of the typical risks exposed to any agricultural based businesses. The supply and quality of FFB are affected in certain seasons or 
weather. For instance, the supply of FFB decrease in the raining season; while the hot weather leads to the shrinkage of the FFB. As far as weather factor is concerned, respondent $C$ shared his strategy to deal with FFB shrinkage risk. In order to get back the portion of the "shrink ton" he sprinkled water on the FFB before transporting the fruits to the mills.

Table 6. Risk in the Fruit Dealers' Business

\begin{tabular}{|c|c|c|}
\hline No. & Risk Themes : & Interview transcripts \\
\hline 1 & $\begin{array}{l}\text { Uncertainty due to unavailable market } \\
\text { (demand) for FFB or rejection by } \\
\text { processing mills }\end{array}$ & $\begin{array}{l}\text { Respondent A } \\
\text { "......Yes, that happened... ....Last year...we have to bear the cost once the lorry } \\
\text { is out (to send the FFB to mills). You know what that has cost us? One lorry } \\
\text { meaning that } 1 \text { tonn of FFB was rejected, so that means RM } 1600 \text { had sunk. Let } \\
\text { say } 10 \text { (lorry) out, we will lose about RM } 16,000 \text { per day....." } \\
\text { Respondent C } \\
\text { "Of course the mills can decide whatever they want. They can simply reject our } \\
\text { fruits. So we have to look for other mills" }\end{array}$ \\
\hline 2 & $\begin{array}{l}\text { Uncertainty due to non-compliance of } \\
\text { FFB according to the prescribed } \\
\text { standard. }\end{array}$ & $\begin{array}{l}\text { Respondent A: } \\
\text { "This XXXX will penalize us if we didn't follow their specifications.... Just } \\
\text { imagine if they come for inspection and find out more than } 5 \% \text { of unqualified FFB, } \\
\text { that will cost you a penalty about RM } 1,600 \text { " } \\
\text { Respondent A: } \\
\text { ".... the processing mills is the one who actually decide whether our FFB should } \\
\text { be rejected or accepted. (For example) one trailler with } 20 \text { tons of FFB, the mills } \\
\text { will decide how many of the fruits are unripe, young, damage. All have its } \\
\text { percentage. Then they will print out the slip and show us the grading results" } \\
\text { Respondent B: } \\
\text { " I do the selection process by myself. Taukeh (refer to himself) must really } \\
\text { expert to look at the fruits whether its ripe or not. If the fruits bunch are not } \\
\text { matured, I will ask them to take back their fruit. If they didn/t take it back I will } \\
\text { throw away the unripe fruit. If the XXXX come and found the unripe FFB, each } \\
\text { young bunch the penalty is about RM } 1,000 \ldots . \text { I think the authority should not } \\
\text { penalize intermediaries like us, they should go for palm oil owners" }\end{array}$ \\
\hline 3. & $\begin{array}{l}\text { Uncertainty of accepting low quality } \\
\text { fruits }\end{array}$ & $\begin{array}{l}\text { Respondent E: } \\
\text { "Sometimes there are smallholders who send unmatured fruit to us. Although } \\
\text { we inspect the fruits thoroughly but sometimes we are unable to detect the } \\
\text { unmatured fruits because they are all mix together..... in that case we have to } \\
\text { dispose the (unmatured) fruit......, we have to get things cleared from our site. I } \\
\text { have to charter lorry to move the fruit from our site and bear the cost." }\end{array}$ \\
\hline 4. & $\begin{array}{l}\text { Uncertainty due to commodity price } \\
\text { fluctuation }\end{array}$ & $\begin{array}{l}\text { Respondent E: } \\
\text { "We purchase fruits from smallholders. Then we send it to the processing mills. } \\
\text { But the mills pay us on a monthly basis once a month. So the price can be lower } \\
\text { that our purchase price" }\end{array}$ \\
\hline 5. & Uncertainty due to weather reason & $\begin{array}{l}\text { Respondent B: } \\
\text { "For this type of business, we encountered risk during the rain season. Once a } \\
\text { year, we will exposed to loss due to the rain season, at least } 2 \text { to } 3 \text { months a year" } \\
\text { Respondent C: } \\
\text { "There is a risk the FFB shrink. For example, the fruits we pluck yesterday will } \\
\text { definitely shrink today. Because of hot weather. Normally once the fruits are } \\
\text { loaded into the lorry, it usually shrink about } 10 \% \text {.... that is my risk." }\end{array}$ \\
\hline
\end{tabular}




\section{Respondent C:}

"I have no choice. At the beginning of my business I used to lose almost 18 tons a year. At that time the price was RM700, the business was good, but yet I don't have money. So started to I investigate and found that it was because the fruits dried and the weight shrink due to hot weather. Since that, I will sprinkle water on the FFB before taking it it to the mills....."

Therefore, the palm oil fruit dealers' business is indeed challenging. This can be concluded from Respondents A experience:

"I once didn't get any pay from this business for 5 years... Nothing for 5 years. Many factors for that loss...20 years ago when I started this business, not many palm oil planted here. I waited 8 to 10 o'clock but the fruits are uncertain. Less fruits, less income, but same expenses. You need to have 4 workers before you can open this business - 1 clerk, 1 manager, 2 drivers. I drove the big truck myself. So end up, I didn't get anything for 5 years. My late father once suggested me to stop (this business) and get employed to earn my living."

\subsection{Competitive Challenge}

Fruit dealer business encountered intense competition due to the existing rivalry. This can be understood from the particular respondents' responds:

\section{Respondent C:}

"Last time we have many clients (smallholders). Now, the number reduced because there many FDs around. Our client was about 200 then, now only 100. We manage to get 500 ton then, now it's difficult even to get 300 ton".

\section{Respondent B:}

"Last year I encountered a loss. Last year there came 2 (new) FDs. We compete on the offered price, until we loss. Before this, I already get a small amount of profit. But last year was worst. I think the profit is only about $R M$ 10,000. .......... let say the official price stated as $R M 40$, the driver and truck assistant (wage) is almost RM 10 per ton, plus fuel, summons, road tax. It was quite easy to make profit from this business then, but nowadays is very difficult because the fruits are lesser but the workers and other expenses remain the same"

\section{Respondent A:}

"I was the second person (to operate fruit dealers' business) in Sg. Besar and Sekinchan areas. Now the competition is really stiff (We ask question on the regulations pertaining distance among FDs in a certain location). On paper, there is a requirement regarding distance of each FDs to one another. The distance is 6 kilometers from one FD to another. .............. On paper there are many requirements (before you entitle to do this business)- 6 kilometers radius, must own 500 acres of palm oil plantation and others... but that was only on paper..."

The FDs found relying on the price tactic to compete with each other. The purchase of FFB must be made according to the current market price. The market price becomes the reference price for all FFB transactions at nationwide. However, some FDs have more advantage because they able to offer premium price compared to other dealers. As a result, the local smallholders tend to sell their FFB to the particular FD who offered them a slightly higher price. This is parallel with Respondent A who expressed his concern over the price strategy of certain competitors' which detriment to the overall market;

\section{Respondent A:}

"There are few FDs who willing to offer slightly higher prices (to smallholders). They don't mind getting very small profit. But their actions actually jeopardize the market. You cannot survive with that price, actually. These guys just want to kill our market...... that's it....."

\section{Respondent B:}

"sometimes my clerk told me that someone calls asking on our price. I know who is on the line. I can recognize their voice. They want to know my price. They want to beat the price.."

In terms of the bargaining power of buyers (in this context "buyers" refer to the palm oil processing mills), most respondents agree the processing mills exert control on the fruit dealers. The mills can choose whether to buy or not from any fruit dealers and have final word on the grade of FFB sent by the fruit dealers. Thus, in 
most cases the FDs have to accept the grade and the price paid by the mills. This can be validated through the interview transcripts:

\section{Respondent A:}

"The mills will choose us (meaning that processing mills determine whether to buy from particular FD or not). We dealers cannot choose mills. Because they have the big power. If they don't like us, we cannot sell to them..need to find somewhere else"

\section{Respondent B:}

"... when we want to sell to mills they will ask us to open the account first. We give them our (business) card, then we go back. After that, we wait for them to come to our office- they will come and check our fruits and so on. If they satisfied, then they will open the account for us. That is their procedure...... We have to follow their procedures"

As a result, the bargaining power of buyers is relatively strong in the palm oil dealers' business. The bargaining power of the suppliers (which refer to the smallholders who supply FFB to the FDs) is also strong because the smallholders can choose to sell their FFB to any FDs.

\section{Respondent B:}

"Some of these smallholders, they ask us to manage the farm, we put the fertilizer, look after the palm tress and so on. But when they get the fruits, they sell it to other FDs. What can we do. We cannot "take back" the fertilizer or the palm tree. We didn't get anything"

\section{Respondent D:}

"Last time we have many clients (smallholders). Now the number reduced because there many FDs around. Our client was about 200 of them, now only 100. We manage to get 500 ton then, but now difficult even to get 300 ton".

The situation shows that each FDs are substitute to one another. The situation occurred because their services are almost identical. As a result, the FDs try to beat each other through higher purchase prices and to offer lower charges for other services.

\section{Discussion and Implications}

This exploratory study indicates that fruit dealers' business is important within the context of palm oil upstream supply chain management. By and large, the FD is a form of agribusiness that has accommodated smallholders of the developing economies such as Malaysia. The FD business benefits the rural farmers by offering variety of services that tally the need of local smallholders. Based on the evidence, the FDs facilitate the smallholders and mills through the offering of two (2) types of services, which are the commercial and social services. The commercial services encompass of (1) FFB trading (purchase and selling); (2) logistics and transportation of FFB, (3) farm management; and (4) selling of agricultural inputs and material. As far as profit is concerned, the FDs gain some profits from the commercial services which are fee-based. The commercial services are customized to fit the needs of local context. For instance, the ageing populations and difficulty of transportation to move the FFB from the plantation site to processing mills, led to the introduction of farm management and transport services by local fruit dealers. Therefore, the FDs have offered additional services that complement their basic service of FFB purchase and selling. The second type of service is the social aid delivered through the provision of informal credit facilities to local smallholders. As a result, FDs business is an accommodating service that supports activities of scattered palm oil smallholders, which hold about 933,948 hectares (16.28 percent) of the Malaysian palm oil plantation in 2016. The FDs managed the logistical aspect of the FFB from the plant site to the mills. Consequently, the smallholders are actually transferring the costs and risks of FFB handling to the FDs. Meanwhile the processing mills also gain benefit as they able to transfer the cost and risk of managing individual smallholders to FDs.

Based on our finding, the FD-smallholders relationship transcends the formal seller-buyer relationship. This is validated by the offerings of informal credit facilities which are not subjected to any stringent approval requirements, zero-interest and with flexible repayment (refer Table 3). All the respondents agree that the loan is a matter of social responsibility. Nevertheless, Respondent E reacts more selectively compared to other four (4) FDs. Respondent E provides credit facilities merely to the trusted person based on their long term relationship. This relates to the local context in which those FDs have been operated. The four (4) FDs in Sabak Bernam, found to have a closer 
relationship with local people and they know each of the smallholders very well. This can be validated through Respondent B description about his relationship with local smallholders/villagers:

"We live in a village, we must help. I cannot do that (referring to any aggressive action to collect loan from smallholders who did not pay their loan). My father also lived here before. I have been here since standard 6. Now, I am already 50 plus... so this place [village] is my home. If I do bad things to the people, they will chase me from here."

The FDs business competition found to be intense due to the existence of many FDs in a nearby area. As a result, the FDs have offered slightly higher price to ensure revenue sustainability. Based on the competitive observation, the fruit dealers' business is not easily entered by all potential market candidates. The barriers come from, (1) the regulation; (2) the capital and operating cost. As far as regulation is concerned, Malaysian Palm Oil Board (MPOB) has specified certain requirements to be complied by potential FDs. The basic requirements for FD license application are as follows:

a) A registered business entities;

b) Possess working capital of at least RM 50,000 (except for the government agencies/cooperative the amount is RM 25,000);

c) Possession of a strategic premise location;

d) Have experience in managing palm oil businesses. This criterion refers to applicant experience, such as owned palm oil business or working with other fruit dealers or have attended courses related to the FFB management; and

e) Providing at least one qualified worker to deal with grading of FFB and have enough space to provide ramp for the grading of FFB.

All potential FDs must comply with the basic requirement prior to application. In addition, the FDs must comply with the specified rules from time to time and inability to comply led to the disapproval of the annual license renewal. Apart from the requirements, the business also needs enormous start-up capital expenditures to purchase physical facilities and working capital as shown in our analysis. Therefore, not all entrepreneurs have the ability to venture the palm oil fruit dealer business. On top of the capital expenditures, the operators also bear the operating expenses on the monthly basis. The operational expenditure for fruit dealers' business consist of wages, transportation, maintenance and overhead. Most of the costs are fixed and it imposed a big challenge to FDs especially during the low fruit season. Another challenge encountered by the FDs is to manage the workers. The FDs who provide additional services also need many workers. They hired the workers from local as well as foreigners. Thus, they exposed to various cost related to the workers' management, such as foreign workers' levy, wages and salary. On top of the risk, the FDs exposed to various uncertainties as shown in Table 6. Most of the risks are beyond the FDs control such as unavailable/rejection of/by buyers/market; price fluctuation, weather condition. Thus, our study expands Chladkova (2008) discussion on the barriers in the agricultural production business, to the context of the palm oil intermediary business.

The competitive structure shows a relatively intense level in which the bargaining power of the buyers and sellers are strong. The mills and the smallholders seem to have power over the FDs. For instance, the smallholders can determine to which FD they want to send the FFB. The situation is far more critical during the low fruit season because the FD will have to compete to get as many FFB as possible from the smallholders. Meanwhile, the mills have power to decide whether to accept (to purchase) the FFB from the particular FDs or not. The situation can be worse during the high fruit season, because the mill may not accept the FFBs due to mills overcapacity or abundance of FFB supply in the market. However, the threat of new entrants is relatively low due to high entrance and exit barriers. As shown in our analysis, the FD business requires high investments due to need of space and location, machineries (such as ramps, forklift and other physical assets), vehicles (truck) and of course cash in hand at all times. Additionally, the FDs have to bear the high operating cost and uncertainty due to the credit facilities, commodity price fluctuation, workers, summon/penalty due to purchase of low grade FFB. The high exit barriers were largely due to the enormous amount of investment in the physical assets. Thus, once getting involved, it is difficult for the FDs to exit from the business. Thus, they attempt to create clients/customer through actions such as lowering the transportation charge, offer relatively higher prices and facilities needed by the smallholders. However, to a certain extent some of the competitive strategy (such as lowering the price too low) endangered the profitability of the whole market in the long run. This situation also shows that rivalry among existing FDs is considerably high 
and each FDs can substitute each other in the market. Thus, the profitability of business is relatively small based on this early finding.

The descriptions of FDs are limited to the Malaysian context. Therefore, we suggest future researchers to include FDs of other developing countries in order to draw generalizations about the nature of the intermediary agribusiness. In addition, similar studies can be conducted across developed countries to observe patterns in a different context. On top of that, future study can include larger samples with a quantitative approach in order to examine variations of FDs performance and the relationship with the owners' entrepreneurial orientation. As far as risk is concerned, the relevant parties, such as the insurance companies, can offer alternative products to manage the inherent risk encountered in the FDs business. Meanwhile, certain funding platforms can be designed to support the start up and operating costs of the palm oil FD ventures. The innovative funding, such as crowdfunding, can be a source of alternative financing to ensure FDs ventures are operating at the best capacity, thus able to deliver the best facilities/services to the local smallholders. These efforts increase the attractiveness of FDs business as well as the number of FD agribusiness in the market. Consequently, the increased competition among the FDs inevitably benefits the smallholders' well-being in long run. This is parallel with Stanton (2000) study who emphasize the role of agribusiness players in current agricultural development.

\section{Conclusion}

Fruit dealers' business is important to accommodate the supply chain of the independent palm oil smallholders in developing nations. The FDs business served the local smallholders with necessary commercial based services as well as the social based services. The risk exposed by the fruit dealers can be classified into two (2) types which is the controllable and non-con controllable risk. The controllable risk comprises of the uncertainty of accepting low quality (such as unripe) FFB. The FDs exercise thorough inspection to mitigate the potential risk of accepting low quality fruit from smallholders. Meanwhile, the non-controllable refers to the external source of risks such as fresh fruit bunch (FFB) shrinkage due to weather conditions, uncertainty of market price and inconsistent mills purchase decisions. Most of the informant did not have any plan to mitigate the identified non-controllable risk. The cost to set up FD business is also enormous and strong cash is necessary to operate the business. This is because the FD need to pay cash for purchase of FFB from smallholders and to bear operating costs as well as to provide the credit facilities for the smallholders. Therefore, future studies related to the accumulation of start-up capital for FD business, such as crowdfunding technique, are indeed necessary. As far as risk is concerned, the relevant parties can offer alternative products to manage the inherent risk encountered in the FDs business. Perhaps, it is time for the insurance companies to observe the nature of FD risk and to offer products that match the risk of FDs agriculture-based businesses. The effort will be able to increase the attractiveness of the agricultural intermediary market. Based on the competitive description, the business found to have a relatively intense competition level because most of the FDs services are very typical to each other. Thus, the substitutability of services among FD in local market is considerably high. Nevertheless, the competition level has benefited the local smallholders.

\section{Acknowledgement}

We would like to acknowledge Universiti Kebangsaan Malaysia (UKM), Malaysian Palm Oil Board (MPOB) and MPOB-UKM Research Endowment for supporting this study. Specifically, MPOB-UKM Research Endowment Grant for funding/supporting this study in two research grants [MPOB-UKM EP-2015-070 \& MPOB-UKM EP 2017-031].

\section{References}

Affendy Arip, M., Lau Sim Yee \& Thien Sie Feng. (2013). Assessing the competitiveness of Malaysia and Indonesia palm oil related industry. World Review of Busienss Research, 3(4), 138-145.

Ahmad Raflis Che Omar, Suraiya Ishak, Abd Hair Awang, Mohd Yusof Hussain, Novel Lyndon \& Abdullah Sanusi Othman. (2016). Orang tengah dalam rantaian pengeluaran pekebun kecil kelapa sawit di Malaysia: satu penemuan awal dari Perak. Geografia Malaysian Journal of Society and Space, 12(5), 161-170.

Awang Ali Bema Dayang Norwana, Rejani Kunjappan, Melissa Chin, Schneveld, G., Potter, L., \& Andriani R. (2011). The local impacts of oil palm expansion in Malaysia: An assessment based on a case study in Sabah state. Working Paper 78, Bogor Barat, Idnoensia, Center for International Forestry Research (CIFOR).

Babbie E. (2004). The Practice of Social Research. Belmont USA: Thomson Wadsworth. 
Barber, J., Metcalfe, S., \& Porteous, M. (1989). Barriers to growth: The ACARD study. In Barber, J. Metcalfe, J.S and Porteous, M., (eds.), Barriers to Growth in Small Firms, New Fetter Lana, London: Routtledge, 1-19.

Boland, M. (2010). Increasing the coordination in the plant and plant product processing and handling sector. Choice, The Magazine of Food, Farm and Resource Issue, 25(4).

Caggese, A. (2012). Entrepreneurial risk, investment, and innovation. Journal of Financial Economics, 106, 287-307. https://doi.org/10.1016/j.jfineco.2012.05.009

Chladkova, D.K.H. (2008). Barriers to the entry into the fruit producing industry in the Czech Republic. Agric. EconCzech, 54(9), 413-418. https://doi.org/10.17221/2700-AGRICECON

Cohen, W. (2011). The purpose of business is not to make a profit. Retrieved from http://www.humanresourcesiq.com/hr-management/columns/the-purpose-of-business-is-not-to-make-a-profit

Dolenc, P., Stubelj, I., \& Laporšek, S. (2012). What is the Objective of a Firm? Overview of Theoretical Perspectives. In Bojnec, S., Brada, J.C., \& Kuboniwa, M. (eds.), Overcoming the Crisis Economics and Financial Development in Asia and Europe. Koper, University of Primorska Press, 51-64.

Elaine Lau Ying Man \& Adam Baharum. (2011). A qualitative approach to identifying major cost influence factors in palm oil mills and the relation towards production cost of crude palm oil. American Journal of Applied Sciences, 8(5), 441-446. https://doi.org/10.3844/ajassp.2011.441.446

Ferrero, I., Hoffman, W.M., \& McNulty, R.E. (2014). Must Milton Friedman embrace Stakeholder Theory. Business and Society Review, 119(1), 37-59

Fossye, E., Harvey, C., McDermott, F., \& Davidson, L. (2002). Understanding and evaluating qualitative research. Australian and New Zealand Journal of Psychiatary, 36, 717-732. https://doi.org/10.1046/j.1440-1614.2002.01100.x

Friedman, M. (2004). The social responsibility of business is to increase its profits. In Beauchamp, T.L., \& Bowie, N.E. Ethical Theory and Business ( $7^{\text {th }}$ ed.). Upper Saddle River, New Jersey, Pearson Education International, 50-55.

Kanchana, R.S., Divya, J.V., \& Beegom, A.A. (2013). Challenges faced by new entrepreneurs. International Journal of Current Research and Academic Review, 1(3), 71-78.

Kuratko, D.F., Morris, M.H., \& Covin. J.G. (2011). Corporate Innovation \& Entrepreneurship (3 ${ }^{\text {rd }}$ d.). Canada: South-Westren Cengage Learning.

Mahfoor Haji Haron, Mad Nasir Shamsudin \& Ismail Abd. Latif. (2001). Challenges for Agribusiness: a case for Malaysia”, International Symposium Agribusiness Management Towards Strengthening Agricultural Development and Trade. Multiple Cropping Center, Chiang Mai University, National Chung Hsing University and The Ministry of Agriculture and Cooperatives.

Mohamed Amine Ben Chikh El Fegoun. Retrieved from http://www.misi.edu.my/3.0/media-files/2015/12/upstream-supply-chain-Analysis-for-Oil-Pal.pdf

Mohammad Haji Alias, Fatimah Mohd Arshad \& Abdul Aziz Abdul Rahman. (1992). Market share analysis of Malaysia's palm oil exports: implications on its competitiveness. Jurnal Ekonomi Malaysia, 26, 3-20.

Olson, K., \& Boehlje, M. (2010). Theme overview: fundamental forces affecting agribusiness industries. Choices The Magazine of Food, Farm and Resources Issue, 25(4).

Porter, M.E. (2008). The five competitive forces that shape strategy. Harvard Business Review. Retrieved from https://mgmt4001winter2012.wikispaces.com/file/view/The+Five+Competitive+Forces+That+Shape+Strategy. pdf

Richter, B. (2009). Enmmvironmental challenges and the controversy about palm oil production-case studies from Malaysia, Indonesia and Mynmar. Hintergrundinformationen Aus Der Internationalen Entwicklungszusammenarbeit Asien und Pazifik.

Stanton, J.V. (2000). The role of agribusiness in development: replacing the diminished role of the government in raising rural incomes. Journal of Agribusiness, 18(2), 173-187.

Suraiya Ishak, Ahmad Raflis Che Omar, Mohd Yusof Hussain, Abd Hair Awang, Novel Lyndon, Abdullah Sanusi Othman \& Mohd Syafiz Akmal Kasimun@Katimon. (2016). Menjejaki mekanisme kawalan ke atas aktiviti orang tengah dalam rantaian pengeluaran hasil pekebun kecil kelapa sawit di Malaysia. Geografia Malaysian 
Journal of Society and Space, 12(4), 46-58.

Teoh Cheng Hai. (2002). The Palm Oil Industry in Malaysia. From Seed to Frying Pan. Retrieved from http://www.rspo.org/files/resources_centre/OP_Chain_Partt\%20Anew.pdf

Vesković, N. (2014). Aspects of entreprnerial risk. Paper presented at FINIZ 2014 - The Role of Financial Reporting in Corporate Governance.

Watson, G. H. (2002). Peter. F. Drucker: Delivering value to customers. Quality Progress, May, 55-61.

Zichella, G. (2015). Risk worth taking- entrepreneurial behavior when faced with risk and uncertainty: a lab experiment. DRUID Academy Conference, Rebild Aalborg, Denmark, 21-23 January. 